\title{
The Potential Market for Improved Varieties of Mangos in Puerto Rican Supermarkets
}

\author{
Frank Mattern and William Pennock ${ }^{1}$
}

\section{INTRODUCTION}

Evaluation of Puerto Rico's current production of mangos indicates that, although they have been grown here since about 1750, the potential for supplying commercial markets is not being met because of shortcomings in the varieties now established in the Island. Most of the fruits are small, have a turpentinic flavor, and a fibrous pulp. Because of these characteristics, locally-grown seedling mangos such as the Mayaguezano and Pasote varieties have a farm value of only about $\$ 6.00$ per thousand fruits. ${ }^{2}$ Most local mangos, therefore, are found along roadsides as shade trees rather than in commercial orchards.

Efforts to introduce fiberless and better-flavored mangos which would be commercially feasible for local growers were begun in 1948 by the Agricultural Experiment Station of the University of Puerto Rico. Since that time, over 150 varieties have been introduced from other areas, planted in several micro-climates of the Island, and their performance and characteristics recorded. After a rigorous selection, the varieties considered most suitable for commercial purposes were planted at the Fortuna Substation in quantities sufficient for feasibility studies. Information is needed now on their potential sales in local as well as New York markets. ${ }^{8}$

Sales amounting to ten million pounds of mangos in the New York City market during 1969 offer Puerto Rico an excellent opportunity for shipping improved mango varieties to that city. There are, however, several reasons why the local market should not be overlooked. Foremost, a pretest of the market for quality mangos conducted in Puerto Rico supermarkets during the 1968 season indicated that demand for this fruit exceeds the supply,

1 Marketing Specialist, and Horticulturist, Agricultural Experiment Station, Mayagüez Campus, University of Puerto Rico, Rlo Piedras, P.R.

The authors express their gratitude to the management and employees of Pueblo Supermarkets for their cooperation in this market test. Also, personnel of the Department of Agricultural Economics were very helpful in the labeling and distribution of the mangos. Special recognition is reserved for Mr. Edgardo González Villafañe and Dr. George E. Pringle, Department of Agricultural Economics and Rural Sociology, and Mr. Luis Alberto Ortiz, Department of Plant Breeding, for their assistance throughout this experiment.

2 Commonwealth Department of Agriculture, Facts and Figures on Puerto Rico's Agriculture, Santurce, P.R., years 1965 to 1969.

The large Latin population in the New York market area exerts a strong demand for the types of fruits and vegetables grown in Puerto Rico. 


\section{JOURNAL OF AGRICULTURE OF UNIVERSITY OF PUERTO RICO}

given the price and other conditions established in the pretest. Furthermore, some of the fruit always will have to be sold locally as it may not be suitable for shipping. An unforeseen event such as a strike could interfere with shipping operations forcing a shipment or an entire crop on the local market. It thus is important that the sales potentiality be determined for both local and New York markets.

This study is concerned with the market potential for improved varieties of mangos in Puerto Rican supermarkets. Consumer preferences and market possibilities are reported for 16 improved varieties. A future publication will provide basic information on the opportunities for sales in the New York market.

\section{PROCEDURE}

This study was conducted in four supermarkets in the San Juan area, a metropolis of about 800,000 persons. Test stores located in Hato Rey, Río Piedras, Bayamón and San Patricio were selected to represent a crosssection of income and social strata.

The fruits were transported weekly from the Fortuna Substation on the south coast of the Island to the Agricultural Experiment Station at RíoPiedras. All mangos were inspected, labeled as to variety, and permitted to ripen for a few days. ${ }^{4}$ They then were delivered in bulls to the supermarkets where they were packaged in cellophane-overwrapped trays according to variety.

A wholesale price of 10 cents and a retail price of 17 cents per pound were established for all varieties under an agreement with the produce buyer for the stores. Data were obtained during the test period from store managers concerning the number of shoppers on specific days and total number of shoppers.

A matched-lot procedure was employed to determine varietal preferences. This required the maintenance of an equal display area for each variety during the test. To obtain data for estimating the market potential for these mangos, the procedure was to simulate the usual way in which supermarkets would handle these fruits if purchased from a local grower. A precise description of the methodologies employed for achieving the objectives of this market test is presented below.

- In pretesting the local market with the 1968 crop it was observed that Puerto Rican shoppers had a strong preference for semiripe mangos. This preference doubtless was derived from previous experience with local varieties. Further, displays of mature-green fruit were quickly disorganized and the mangos were bruised by excessive handling and squeezing. To avoid this, fruits were displayed after partial ripening. 


\section{DETERMINATION OF CONSUMER VARIETAL PREFERENCES}

The supermarket at the Las Americas Shopping Center in Hato Rey was selected for the study of consumer preferences for different varieties of improved mangos. The test store is located in a 78-store complex which is the largest shopping center by far in Puerto Rico. With a large number of retail outlets, a fairly wide range of income groups are attracted to the area. The clients of the selected store, therefore, can be considered to represent a wider range of Puerto Rican shoppers than customers of an average neighborhood-type supermarket.

Sixteen improved varieties of mangos were available for the test, namely: Springfels, Ruby, Irwin, Davis Haden, Edward, Haden, Parvin, Zill, Jacqueline, Early Gold, Kent, Sensation, Julie, Pillsbury, Eldon, and Lippens. These varieties include large, medium, and small sizes as well as different colored fruits. The selection also includes early, middle, and late season varieties. Because of seasonality, all 16 varieties were not tested simultaneously. However, some uniformity in rating was achieved by having eight varieties displayed at any one time throughout the test period. ${ }^{5}$ The number of times that each type was included in the test depended on the availability of the fruits as affected by the number of bearing trees, production per tree, and length of its bearing season.

To compare consumer preferences, equal numbers of cellophane-overwrapped trays of each of the eight varieties being tested at one time were displayed together. All fruits were priced at 17 cents per pound. Replacements were made as the mangos were sold so that each variety was exposed equally to the shoppers on any given day. The number of replaced trays of each variety was recorded and computed as a percentage of the number of shoppers in the supermarket during the selling period. This established an acceptance rating for each variety (table 1 ).

Rating each variety according to its sales per 100 shoppers confirmed a pretest observation that the popularity of a mango variety with Puerto Rico supermarket customers is determined largely by the coloration and size of the fruit. Springfels, for example, which is a large and colorful mango, obtained a rating of 2.178; whereas, Lippens, because of its small size and green color, was rated at only 0.147 . The acceptance ratings of the varieties

5 Undoubtedly, the preference rating of any variety would be affected to some extent by the customer appeal of other varieties displayed coincidentally. This largely is contingent on its bearing season with relation to other available varieties at the time and may simply be regarded as one of the characteristics which affect its desirability. Any variety has to compete primarily with others with which it coincides in season and should be rated on that basis. 
within these extremes are related directly to their degree of coloration and comparative size.

As a possible indication of the importance of size and color, the sales of Ruby and Eldon provide an interesting comparison. Ruby was the smallest of the varieties tested but has a very attractive red color whereas, Eldon is large but frequently green colored. The acceptance rating of 1.316 for the Ruby compared with 0.353 for the Eldon indicates that attractive coloring was more important than size in this market test.

TABLE 1.-Trays of improved mangos sold, number of shoppers, and acceptance ratings by varieties, one supermarket, Hato Rey, Puerto Rico, 1969

\begin{tabular}{rlrrr}
\hline Rank & \multicolumn{1}{c}{ Variety } & Trays sold & Shoppers & Acceptance rating \\
\hline & & Number & Number ${ }^{2}$ & \\
1 & Springfels & 100 & 4,591 & 2.178 \\
2 & Ruby & 150 & 11,400 & 1.316 \\
3 & Irwin & 88 & 6,924 & 1.271 \\
4 & Davis Haden & 57 & 4,984 & 1.144 \\
5 & Edward & 38 & 3,870 & 0.982 \\
6 & Haden & 31 & 3,401 & 0.911 \\
7 & Parvin & 59 & 8,170 & 0.722 \\
8 & Zill & 65 & 9,045 & 0.719 \\
9 & Jacqueline & 76 & 10,677 & 0.712 \\
10 & Early Gold & 4 & 640 & 0.625 \\
11 & Kent & 61 & 11,224 & 0.543 \\
12 & Sensation & 29 & 5,409 & 0.536 \\
13 & Julie & 21 & 5,815 & 0.361 \\
14 & Pillsbury & 44 & 12,333 & 0.357 \\
15 & Eldon & 35 & 9,927 & 0.353 \\
16 & Lippens & 12 & 8,170 & 0.147 \\
\hline
\end{tabular}

1 Number of trays sold per 100 shoppers.

Taken from cash register receipts at the check-out counters.

The significance of differences between the acceptance rating of the mango varieties are shown in table 2. The following comparisons are particularly noticeable:

1. The Springfels variety was significantly more acceptable than any of the other varieties tested.

2. There were no significant differences between Ruby, Irwin, and Davis Haden, but these were all significantly more acceptable than Parvin or the nine varieties with ratings lower than Parvin.

3. Kent, which had been considered one of the most acceptable of the varieties, received a low rating of only 0.543 .

4. There were no significant differences between Sensation, Julie, Pills- 
TABLE 2.-Significance of differences ${ }^{1}$ among the percenlage acceplance ratings of the mango varieties shown in table 1

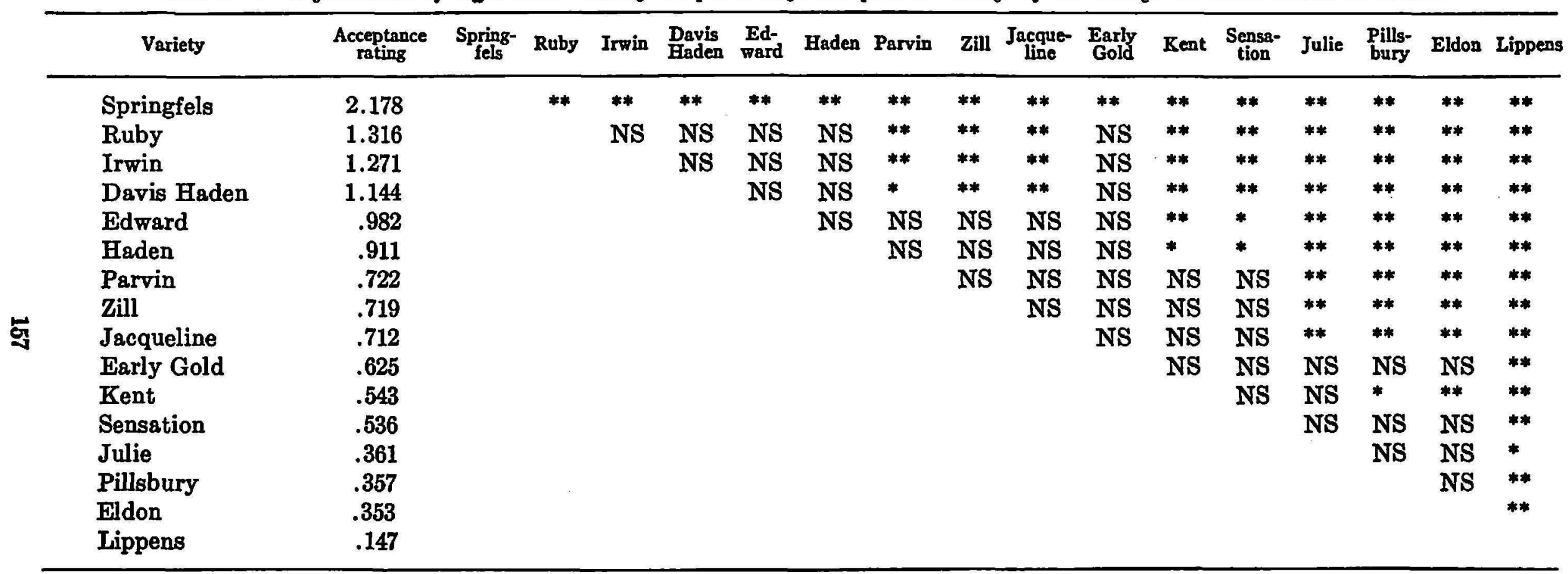

'Significance of differences as indicated by the " $t$ " test.

N.S. = Not significant

* = Significant at 5-percent level

** = Significant at 1-percent level 
bury, and Eldon, which formed a group showing the second lowest acceptance.

5. Lippens had a significantly lower rating than all other varieties.

\section{ESTIMATION OF WEEKLY MANGO SALES IN PUERTO RICAN SUPERMARKETS ${ }^{\circ}$}

To obtain data for estimating the potential market for improved varieties of mangos in Puerto Rican supermarkets, the procedure was to follow everyday operating practices of the store as closely as possible throughout the experiment. There was neither promotion within the stores nor through ordinary advertising channels. In all the stores, the display of the fruits was the responsibility of the produce manager rather than of the survey personnel. The mangos were packaged in cellophane-overwrapped trays and displayed on Friday or Saturdays for a 6-week period. The supermarkets were located in Río Piedras, Bayamón, and San Patricio.

Sales for each test day were obtained by recording the weight of the fruits displayed in each supermarket at the beginning of the day and subtracting the weight of the fruits remaining at the end of the day. The total number of pounds of mangos sold then were divided by the number of shoppers in the store during the day to determine sales per shopper. Under the conditions established in the study, average sales per week in the three supermarkets ranged from 0.0933 to 0.1043 pounds of mangos per customer. In these stores, 0.0987 pounds of mangos were sold per shopper during the 6-week test period (table 3). Because of the small variation in per-customer sales among the three stores, an estimation of market potentials for improved mangos was made by expansion of the results obtained from the test stores to all the supermarkets in Puerto Rico.

In accordance with information provided by the management, a total of 36,249 customers visited the four supermarkets each week during the 6 -week period encompassed by the study. Management also reported that the four test stores represent 25 percent of the chain's total sales in Puerto Rico. Assuming that the test stores also account for one-fourth of the chain's total customers, expansion of customer data from test stores would indicate 144,996 shoppers for the entire chain. If the additional assumption is made that the chain accommodates 30 percent of supermarket shoppers in the entire Island, or the same proportion that the chain holds of total supermarket sales in Puerto Rico, an estimate of 483,320 supermarket shoppers may be made for all the Island supermarkets. Potential sales of mangos in Puerto Rican supermarkets may then be determined by applying a multiplier of 0.0987 to the estimated number of customers. Priced at 17 cents per

- For this market test, a supermarket is defined as a retail food store having at least 300 square feet of sales area and a self-service system. 
TABLE 3.-Pounds of mangos sold, number of shoppers, and sales per shopper, three supermarkets, San Juan, Puerto Rico, 1969

\begin{tabular}{|c|c|c|c|}
\hline Store and date & Pounds sold & Shoppers & Sold per shopper \\
\hline Supermarket No. 1 & Number & Number 1 & Pounds \\
\hline $\begin{array}{l}28 \text { June } \\
5 \text { July } \\
11 \text { July } \\
19 \text { July } \\
26 \text { July } \\
1 \text { August }\end{array}$ & $\begin{array}{l}176 \\
130 \\
177 \\
217 \\
257 \\
170\end{array}$ & $\begin{array}{l}2,085 \\
1,894 \\
1,415 \\
2,066 \\
2,450 \\
2,224\end{array}$ & $\begin{array}{r}0.0865 \\
.0686 \\
.1251 \\
.1050 \\
.1049 \\
.0764\end{array}$ \\
\hline $\begin{array}{l}\text { Sub-total } \\
\text { Daily average }\end{array}$ & $\begin{array}{r}1,127 \\
188\end{array}$ & $\begin{array}{r}12,084 \\
2,014\end{array}$ & .0933 \\
\hline $\begin{array}{l}\text { Supermarket No. } 2 \\
28 \text { June } \\
5 \text { July } \\
11 \text { July } \\
19 \text { July } \\
26 \text { July } \\
1 \text { August }\end{array}$ & $\begin{array}{l}160 \\
171 \\
191 \\
409 \\
334 \\
325\end{array}$ & $\begin{array}{l}2,548 \\
2,327 \\
2,393 \\
2,013 \\
3,237 \\
2,717\end{array}$ & $\begin{array}{r}0.0628 \\
.0735 \\
.0798 \\
.2032 \\
.1032 \\
.1196\end{array}$ \\
\hline $\begin{array}{l}\text { Sub-total } \\
\text { Daily average }\end{array}$ & $\begin{array}{r}1,590 \\
265\end{array}$ & $\begin{array}{r}15,235 \\
2,539\end{array}$ & .1043 \\
\hline $\begin{array}{l}\text { Supermarket No. } 3 \\
28 \text { June } \\
5 \text { July } \\
11 \text { July } \\
19 \text { July } \\
26 \text { July } \\
1 \text { August }\end{array}$ & $\begin{array}{l}280 \\
151 \\
160 \\
170 \\
201 \\
296\end{array}$ & $\begin{array}{l}1,794 \\
2,015 \\
2,326 \\
1,878 \\
3,029 \\
1,922\end{array}$ & $\begin{array}{r}0.1561 \\
.0749 \\
.0688 \\
.0905 \\
.0664 \\
.1540\end{array}$ \\
\hline $\begin{array}{l}\text { Sub-total } \\
\text { Daily average }\end{array}$ & $\begin{array}{r}1,258 \\
210\end{array}$ & $\begin{array}{r}12,964 \\
2,160\end{array}$ & .0970 \\
\hline $\begin{array}{l}\text { Total all stores } \\
\text { Daily average, all stores }\end{array}$ & $\begin{array}{r}3,975 \\
221\end{array}$ & $\begin{array}{r}40,283 \\
2,238\end{array}$ & .0987 \\
\hline
\end{tabular}

1 Taken from cash register receipts at checkout counters.

pound, weekly sales of 47,704 pounds of mangos of improved varieties such as Springfels, Ruby, and Irwin are indicated for Puerto Rican supermarkets.

\section{SUMMARY}

Mangos have a long history in Puerto Rico but traditional varieties offer little if any economic incentive for commercial production. Improved varieties therefore have been introduced to the Island. 
A matched-lot procedure was employed to determine consumer preferences for different improved varieties of mangos. Of 16 varieties tested, Springfels was the most popular, with Ruby, Irwin, and Davis Haden following. In addition to these four varieties, Edward, Haden, Parvin, Zill, Jacqueline, Early Gold, Kent, and Sensation also were rated rather highly. Julie, Pillsbury, Eldon, and Lippens had little consumer appeal when compared with the other varieties in this market test.

The market potential for improved varieties of mangos in Puerto Rican supermarkets was estimated by expanding data gathered in three test supermarkets to all Island supermarkets. In the test stores, 0.0987 pounds of mangos per shopper were sold during a 6-week test period. This multiplier was applied to the estimated total number of Puerto Rican supermarket shoppers, which rendered estimated sales of 47,704 pounds per week at 17 cents per pound.

\section{RESUMEN}

Aunque el mangó se ha producido en Puerto Rico durante muchos años, las variedades corrientes del país no ofrecen un incentivo para su producción comercial debido a su bajo precio de venta. Por tal razón se han introducido a Puerto Rico variedades selectas de mejor apariencia y calidad.

Para determinar las preferencias del consumidor se puso a la venta simultáneamente en tres supermercados igual cantidad de ocho distintas variedades, reponiéndose las unidades vendidas a intervalos cortos de manera que las cantidades disponibles de cada variedad no influyeran en la selección por el consumidor. En total se vendieron 16 distintas variedades, empezando con las de madurez más temprana y terminando con las más tardías, pero siempre mostrando a la vez ocho de las que coincidían en cuanto a su época de cosecha.

La variedad Springfels fue la que tuvo mayor aceptación seguida por Ruby, Irwin y Davis Haden en ese mismo orden. A estas cuatro variedades le siguieron en orden de aceptación la Edward, Haden, Parvin, Zill, Jacqueline, Early Gold, Kent y Sensation, mientras que la Julie, Pillsbury, Eldon y Lippens fueron las menos aceptables.

El mercado potencial para estas variedades de mangó en Puerto Rico se calculó a base de las ventas registradas en tres supermercados, las cuales guardan una proporción aproximada con las ventas totales de todos los supermercados en la Isla. En los supermercados en que se hicieron las pruebas el promedio de compras de mangó durante las 6 semanas de prueba fue de 0.0987 de libra por persona por semana. Multiplicando esta cifra por el número de compradores en todos los supermercados de la Isla, se estimó que existe un mercado potencial en Puerto Rico de 47,704 libras de mangó por semana. 